\title{
KLASIFIKASI HABITAT PERAIRAN DANGKAL BERBASIS OBJEK MENGGUNAKAN CITRA WORLDVIEW 2 DAN SENTINEL 2B DI PERAIRAN KEPULAUAN SERIBU
}

\section{CLASSIFICATION OF SHALLOW WATER HABITAT BASED ON OBJECT USING WORLDVIEW 2 AND SENTINEL $2 B$ IMAGES IN KEPULAUAN SERIBU WATERS}

\author{
Esty Kurniawati ${ }^{1 *}$, Vincentius Siregar ${ }^{2}$, \& I Wayan Nurjaya ${ }^{2}$ \\ ${ }^{1}$ Program Studi Teknologi Kelautan, Sekolah Pascasarjana, IPB University, Bogor, 16680, Indonesia \\ ${ }^{2}$ Departemen Ilmu dan Teknologi Kelautan, FPIK, IPB University, Bogor, 16680, Indonesia \\ *E-mail: estykurniawati93@gmail.com
}

\begin{abstract}
The benthic habitats of shallow waters of Sebaru Island and Lancang Island have different water characteristics from geographical location. Data and information about benthic habitat are needed to maintain and preserve ecosystems in the waters. This study aims is to know the effect of different satellite image resolution, different algorithms and water quality e.g chlorophyll-a (Chl-a) and total suspended solid (TSS) on the accuracy of shallow-water benthic habitats mapping on Sebaru Besar Island and Lancang Island. The accuracy (OA) of the application of different classification algorithms showed a good results. The highest OA results in shallow waters of Sebaru Island with Wordview 2 imagery were obtained from the SVM and DT algorithms with the same value of 76.24\%, while the Sentinel $2 B$ image with the DT algorithm obtained results (OA) of 68.08\%. In Lancang Island the highest $O A$ value of Wordview 2 imagery was obtained by DT algorithm with a value of $74.44 \%$, while Sentinel 2B imagery was obtained from KNN algorithm with a value of 59.0\%. High concentrations of Chl-a and TSS cannot yet be said to affect the low accuracy in mapping shallow water benthic habitats.
\end{abstract}

Keywords: benthic habitats, DT, Kepulauan Seribu Waters, KNN, OBIA, SVM

\begin{abstract}
ABSTRAK
Habitat bentik perairan dangkal Pulau Sebaru dan Pulau Lancang memiliki karakteristik perairan yang berbeda dari letak geografisnya. Keperluan data dan informasi tentang habitat bentik sangat di perlukan untuk menjaga dan melestarikan ekosistem yang ada di perairan. Penelitian ini bertujuan untuk mengetahui pengaruh perbedaan resolusi citra satelit, penggunaan algoritma yang berbeda dan kualitas perairan (khususnya param klorofil (Chl-a), total suspended solid (TSS)) terhadap akurasi pemetaan habitat bentik perairan dangkal di Pulau Sebaru Besar dan Pulau Lancang. Overall accuracy (OA) dari penerapan algoritma klasifikasi SVM, KNN dan DT menunjukkan hasil yang baik. Hasil OA tertinggi di perairan dangkal Pulau Sebaru Besar dengan Citra Wordview 2 diperoleh dari algoritma SVM dan DT dengan nilai yang sama yaitu 76,24\%, sedangkan dari Citra Sentinel 2B dengan algoritma DT diperoleh hasil OA sebesar 68,08\%. Perairan dangkal Pulau Lancang nilai OA tertinggi dari Citra Wordview 2 diperoleh dengan algoritma DT dengan nilai sebesar 74,44\%, sedangkan Citra Sentinel 2B diperoleh dari algoritma KNN dengan nilai sebesar 59,04\%. Tinggi konsentrasi Chl-a dan TSS belum dapat dikatakan memengaruhi rendahnya akurasi dalam pemetaan habitat bentik perairan dangkal.
\end{abstract}

Kata Kunci: DT, habitat bentik, Kepulauan Seribu, KNN, OBIA, SVM

\section{PENDAHULUAN}

Ekosistem di perairan dangkal terbentuk dari beberapa habitat bentik dan organis- me asosiasi. Habitat bentik di perairan memiliki keragaman yang berbeda-beda tergantung pada lokasi dan kedalaman perairan. Pulau Sebaru Besar dan Pulau Lancang yang 
merupakan bagian dari gugusan Kepulauan Seribu memiliki ekosistem habitat bentik yang cukup beragam. Pulau Sebaru Besar adalah salah satu pulau yang terletak di bagian utara Kepulauan Seribu, dan merupakan pulau tidak berpenghuni yang memiliki ekosistem karang, mangrove, Seagrass, dan biota laut beragam. Hal ini berbeda dengan kondisi di perairan Pulau Lancang yang memiliki penduduk cukup padat. Pulau Lancang memiliki perairan yang lebih keruh dibandingkan Pulau Sebaru Besar karena adanya kegiatan pembangunan dan reklamasi.

Perairan Kepulauan Seribu merupakan perairan yang berada dekat dengan Teluk Jakarta, secara oseanografis berhubungan langsung dengan 13 muara sungai. Perairan Teluk Jakarta telah mengalami perubahan dan kemungkinan telah menyebabkan kerusakan pada lingkungan perairan sekitarnya, hal tersebut disertai dengan menurunnya kualitas air laut sehingga menyebabkan padatnya pemukiman, kegiatan industri, transportasi dan perdagangan (Firmansyah et $a l$. , 2012). Hal ini menyebabkan rusaknya habitat dan berimbas pada biota dan ekosistem yang ada disekitarnya. Peng et al. (2013) menyatakan kerusakan atau penurunan kualitas habitat bentik sebagai akibat dari peningkatan konsentrasi unsur-unsur kimia (polutan) di kolom perairan. Oleh karena itu, untuk mengetahui dan memantau kondisi perairan dan habitat perairan dangkal perlu dilakukannya pemetaan. Pemetaan habitat bentik dapat dimanfaatkan sebagai informasi sumberdaya laut, informasi penentuan kawasan perlindungan dan pengelolaan laut.

Teknik pengindraan jauh dapat digunakan secara efektif dalam mengamati dan memantau sebaran habitat bentik pada perairan dangkal dengan membedakan karakteristik karang, keanekaragaman habitat dan zonasi laut (Andréfouët et al., 2001). Kemajuan dalam pemprosesan citra dilakukan dengan pendekatan Object Based Image Analysis (OBIA). OBIA merupakan pen- dekatan teknik klasifikasi yang berkembang setelah teknik klasifikasi berbasis piksel (Pena et al., 2013). Pendekatan metode OBIA menggunakan nilai reflektan, tekstur, shape, nilai layer-based, konteks object dan properti biofisik dari kelompok piksel atau objek (Roelfsema et al., 2010; Blaschke et al., 2014).

Pemetaan habitat bentik dengan pendekatan OBIA telah banyak dilakukan oleh para peneliti sebelumnya dan memiliki hasil yang baik. Hasil penelitian sebelumnya menggunakan Citra Landsat 8 dengan algoritma klasifikasi SVM, RT, KNN dan DT menghasilkan OA masing-masing 73\%, 68\%, $67 \%$ dan $56 \%$ (Wahidin et al., 2015). Klasifikasi habitat bentik dengan OBIA dari citra UAV di perairan Pulau Wangi-Wangi diperoleh OA dengan algoritma SVM sebesar $77,4 \%$ dengan 12 kelas dan $81,1 \%$ dengan 9 kelas dengan skala segmentasi 50 (Mastu et al., 2018). Sementara itu hasil klasifikasi citra Sentinel-2 dengan metode OBIA diperoleh OA sebesar 60,4\% untuk 12 kelas dan $64,1 \%$ untuk 9 kelas dengan menggunakan algoritma SVM (Mastu et al., 2018).

Penelitian ini menggunakan citra yang memiliki resolusi yang berbeda, yaitu Citra Worldview 2 dan Sentinel 2B. Penelitian ini bertujuan untuk mengetahui kemampuan kedua citra dalam memetakan habitat perairan dangkal. Citra Sentinel 2B merupakan citra yang mudah didapatkan dan bersifat open source sehingga dapat menjadi alternatif dalam pemetaan habitat bentik perairan. Algoritma SVM, KNN dan DT digunakan pada dua lokasi dan karakteristik berbeda serta menggunakan dua citra dengan resolusi yang berbeda.

Sebaran habitat bentik pada setiap wilayah tidak merata karena dipengaruhi oleh kondisi lingkungan laut yang berbeda. Hal ini berkaitan dengan karakteristik oseanografi dan aktivitas antropogenik. Adanya aktivitas penduduk dan pembangunan yang berlebihan tanpa memperhatikan dampaknya terhadap lingkungan akan mengakibatkan penurunan kualitas perairan di sekitarnya. Faktor antro- 
pogenik yang dapat merusak ekosistem laut terutama disebabkan oleh eksploitasi yang berlebihan, proses penangkapan ikan, polusi dan perubahan iklim (Keller et al., 2009). Aktivitas tersebut akan menghambat perkembangan ekosistem laut di sekitarnya.

Tujuan penelitian ini adalah untuk mengetahui adakah pengaruh perbedaan resolusi citra satelit, penggunaan algoritma yang berbeda dan kualitas perairan (khususnya param Chl-a, TSS) terhadap akurasi pemetaan habitat bentik perairan dangkal di Pulau Sebaru Besar dan Pulau Lancang.

\section{METODE PENELITIAN}

\subsection{Waktu dan Tempat Penelitian}

Proses pengambilan data di lapangan dilakukan selama 7 hari, yaitu pada tanggal 5-11 Desember 2018 di Pulau Sebaru Besar dan Pulau Lancang, Kepulauan Seribu
(Figure 1). Pengolahan dan analisis data dilakukan pada bulan Desember hingga bulan April 2019 di Laboratorium Pemetaan dan Pemodelan Spasial Fakultas Perikanan dan Ilmu Kelautan, Departemen Ilmu dan Teknologi Kelautan, IPB University.

\subsection{Alat dan Bahan}

Peralatan yang digunakan pada penelitian ini adalah perangkat keras berupa personal computer intelcore i3, RAM 4 GB dengan media penyimpanan 500 GB.

Perangkat lunak yang digunakan adalah microsoft dan beberapa software pendukung pengolahan data seperti ENVI 5.3, ArcGis dan eCognition Developer 9.0. Peralatan yang digunakan untuk pengambilan sampel air pada pengukuran konsentrasi Chla dan TSS menggunakan botol sampel serta peralatan perekaman data koordinat, dokumentasi, pengukuran dan pencatatan data.

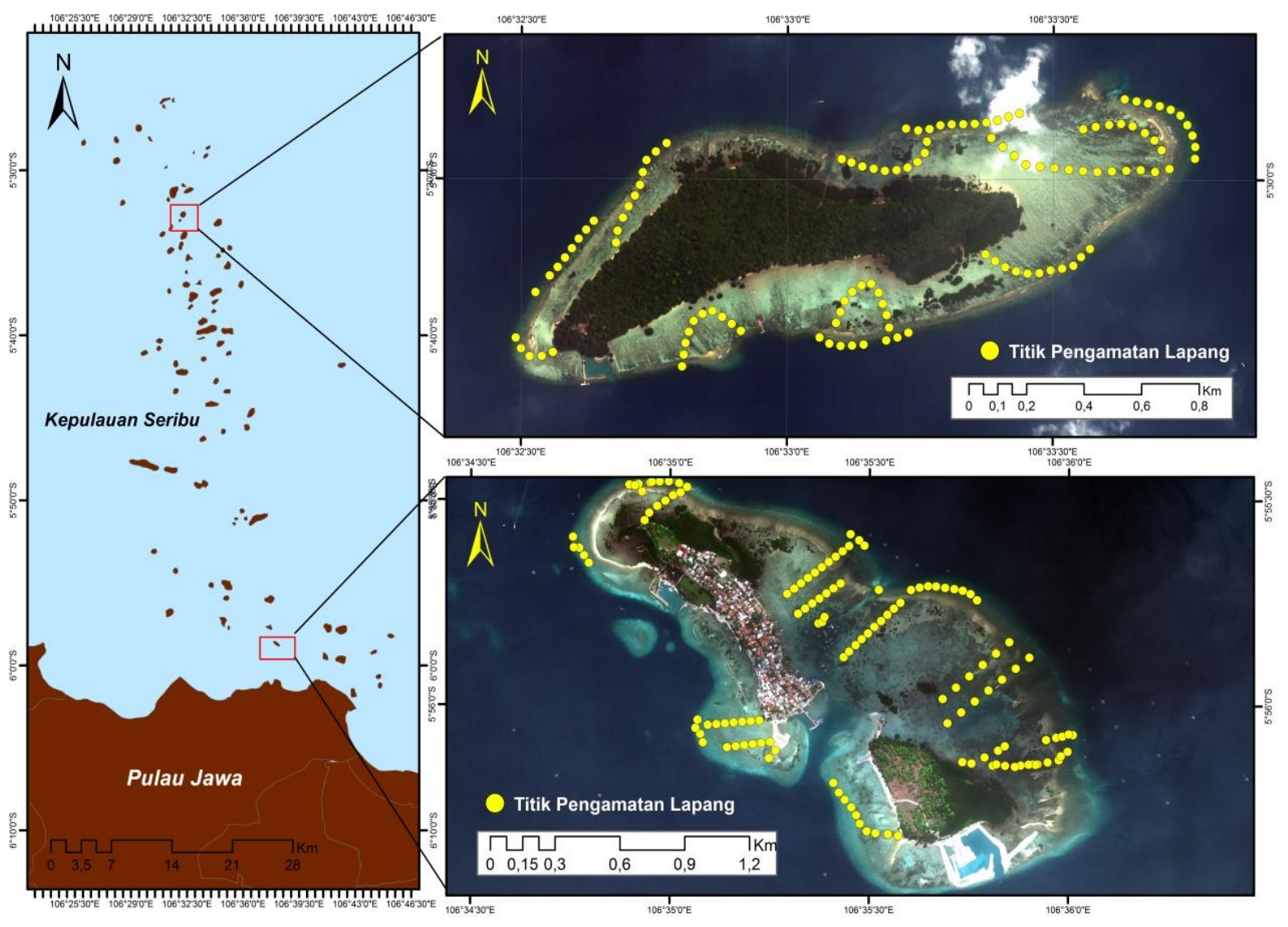

Figure 1. Map of research location (source: Citra Worldview 2). 


\subsection{Data Citra Satelit}

Data citra yang digunakan adalah Citra multispektral Worldview 2 dengan akusisi tanggal 7 Juni 2018 dan Citra Sentinel 2B pada 15 Mei 2017. Citra WorldView 2 memiliki 8 band (coastal, blue, green, yellow, red, red-edge, NIR1, NIR2) dengan resolusi spasial pankromatik $0,46 \mathrm{~m}$ dan 1,85 m untuk multispketral dengan P123 dan R64. Citra Sentinel 2B memiliki 13 band dan resolusi spasial 60 hingga $10 \mathrm{~m}$. Identifikasi habitat bentik dilakukan dengan menggunakan metode transect quadrat $1 \mathrm{~m} \mathrm{x}$ $1 \mathrm{~m}$ dan $10 \mathrm{~m} \times 10 \mathrm{~m}$. Jumlah titik pengamatan di Pulau Sebaru Besar sebanyak 149 titik dan di Pulau Lancang sebanyak 125 titik pengamatan. Pengukuran Chl-a dan TSS dilakukan pada 10 titik sampel pada Pulau Sebaru Besar dan 12 titik sampel pada Pulau Lancang.

\subsection{Pemrosesan Citra}

Pengolahan citra tahap awal adalah melakukan pembatasan lokasi penelitian (cropping citra), kemudian dilanjutkan dengan koreksi geometrik, radiometrik, dan atmosfer. Koreksi geometrik menggunakan tool image registration workflow dengan teknik transformasi Ground Control Ponit (GCP). Koreksi radiometrik yang dilakukan adalah dengan mengubah nilai digital piksel menjadi radiance. Nilai digital piksel yang diterima oleh sensor satelit dari pantulan sebuah objek perlu dikonversikan menjadi randiance yang dihitung pada setiap kanal dari sensor satelit. Metode koreksi atmosferik yang digunakan adalah metode FLASSH (Fast Line-of-sight Atmospheric Analysis of Spectral Hypercube).

Tahap kedua adalah proses klasifikasi citra dengan metode OBIA yang diaplikasikan pada eCognition Developer 9.0. Metode OBIA secara keseluruhan dibagi menjadi dua bagian, yaitu proses segmentasi citra dan proses klasifikasi. Proses segmentasi citra merupakan proses yang menghasilkan objek/kelompok piksel yang memiliki sifat yang sama. Proses pengelompokan objek pada proses segmentasi dilakukan dengan menentukan skala segmentasi yang digunakan. Pada penelitian ini skala segmentasi yang digunakan dalam proses klasifikasi yaitu dengan algoritma SVM, KNN, dan DT, sedangkan Citra Worldview 2 menggunakan skala segmentasi 25, dan pada Citra Sentinel 2B dengan skala segmentasi 15 . Proses selanjutnya yaitu proses klasifikasi. Proses klasifikasi menggunakan skema klasifikasi dari persentase habitat bentik data lapang yang diklasifikasi dengan metode Agglomerative Hierarhical Clustering (AHC).

Semua titik pengamatan data lapangan (in situ) di Pulau Sebaru Besar dan Pulau Lancang yang berjumlah 274 titik dianalisis dengan metode AHC, selanjutnya data tersebut dibagi menjadi dua data, yaitu data untuk input klasifikasi dan data untuk uji akurasi. Klasifikasi habitat bentik pada metode OBIA menggunakan algoritma Support Vector Machinee (SVM), $k$-Nearest Neighbour (KNN) dan Decision Tree (DT). Formula algoritma SVM dapat ditulis sebagai berikut (Tzotsos, 2006) :

$$
f(x)=\sum_{i \in S} \lambda_{i} y_{i} K\left(x_{i} x\right)+w_{0}
$$

$K$ merupakan fungsi kernel, $y_{i}$ dan $x_{i}$ mewakili sampel pelatihan, $\lambda_{i}$ merupakan pengganda Lagrange, $S$ bagian dari sampel pelatihan yang sesuai dengan pengganda Lagrange non-zero, dan $w_{0}$ adalah param hyperplane.

Konsep dasar dari klasifikasi algoritma KNN adalah bahwa data yang paling dekat dengan data yang diklasifikasikan dalam ruang fitur akan cenderung dikelompokkan menjadi satu kelas yang sama daripada data yang berjauhan (Atkinson \& Naser, 2010). Formula didefinisikan sebagai berikut (Wei et al., 2005):

$$
d={\sqrt{\sum_{f}\left[\frac{v_{f}^{(s)}-v_{f}^{(o)}}{\sigma_{f}}\right]^{2}}}^{2}
$$


$d$ merupakan jarak antara objek sampel $s$ dan objek gambar $o, v_{f}^{(s)}$ nilai fitur objek sampel untuk fitur $f, v_{f}^{\text {(a) }}$ nilai fitur objek gambar untuk fitur $f, \sigma_{f}$ standar deviasi dari nilai fitur untuk fitur $f$.

DT dapat menentukan suatu keputusan menggunakan struktur hierarki atau pohon keputusan yang mirip dengan diagram alur yang mampu mendapatkan nilai target dengan analisis dan klasifikasi (Liao \& Sun, 2010). Masalah utama untuk membangun pohon keputusan adalah menemukan atribut yang tepat dan pemisahan (split) optimal untuk domain param. Kriteria pemisahan adalah memiliki gain entropy yang maksimum dengan formula sebagai berikut (Chen et al., 2014):

$$
\begin{aligned}
& \operatorname{Gain}(S, A)=E(S)-\sum_{v} \frac{\left|S_{v}\right|}{|S|} E\left(S_{v}\right) \\
& E(S)=\sum_{i=1}^{N}-p_{i} \log _{2} p_{i}
\end{aligned}
$$

Gain ( $S, A)$ merupakan gain entropy dari sampel $S$ yang dibagi pada atribut $A, E(S)$ adalah entropi dari sampel $S, \quad S v$ adalah sampel milik subset $v$, dan $E(S v)$ adalah entropinya. Perhitungan entropy pada persamaan 4, dimana pi adalah proporsi sampel yang dimasukkan ke dalam subset $i$. Konsep dasar SVM adalah dengan mencari hyperplan pemisah terbaik dengan mengukur margin atau jarak antara hyperplane (C) dan mencari titik maksimal pemisah antar kelas (Wahidin, 2015). Konsep dasar dari klasifikasi algoritma KNN adalah mengelompokkan data yang paling dekat dengan data yang diklasifikasikan $(k)$ dalam ruang fitur akan cenderung menjadi satu kelas yang sama daripada data yang berjauhan (Atkinson \& Naser., 2010). Algoritma DT menerapkan aturan untuk memisahkan data ke dalam berbagai kategori. Menggunakan aturan logika biner (if... and... then...) yang diatur pada hierarki (pohon). Aturan tersebut dilakukan secara berurutan untuk mencapai target kelas informasi (Verhulp \& Niekerk, 2017).

\subsection{Analisis Data Oseanografi}

Penentuan titik sampling pada masing-masing pulau dilakukan dengan metode simpel random sampling. Metode simpel random sampling adalah cara pengambilan sampel yang dilakukan secara acak tanpa memperhatikan strata (tingkatan) yang ada dalam populasi (Sugiyono, 2008). Pengukuran Chl-a dan TSS dengan cara mengambil sampel air. Analisis material terlarut dengan menggunakan kertas saring (glass fibel filter) Whatman Grade 934 AH dengan perhitungan APHA (2012) sebagai berikut:

$T S S=\frac{(A-B) x 1000}{\text { volume sampel }(\mathrm{mL})}$

$A$ merupakan berat kertas saring dengan suspensi terlarut kering $(\mathrm{mg})$ dan $B$ merupakan berat kertas tanpa suspensi terlarut kering (mg).

Konsentrasi Chl-a dihitung dengan persamaan APHA (2012), sebagai berikut:

$C h l-a=\frac{C a x V a}{V x d}$

$V a$ merupakan volume aseton $(10 \mathrm{ml}), V$ adalah volume sampel air yang di saring $(\mathrm{ml}) . d$ adalah diameter cuvet $(1 \mathrm{~mm}) . C a$ merupakan perhitungan nilai absorsi $(11,6 \mathrm{x}$ E665) - (1,31 x E645) - (0,14 x E630) dan $E$ merupakan absorbansi pada panjang gelombang yang berbeda (yang dikoreksi dengan panjang gelombang $750 \mathrm{~nm}$ ).

\subsection{Akurasi Citra}

Uji akurasi hasil klasifikasi bentik habitat dilakukan dengan matriks kesalahan (error matrix/confusion matrix). Akurasi terdiri dari OA, producer accuracy (PA), user accuracy (UA), Kappa statistik, dan Z-test. OA merupakan persentase ketelitian dari keseluruhan klasifikasi yang menunjukkan banyaknya jumlah piksel yang terklasifikasi secara benar. Producer accuracy (Omission 
Errors) adalah persentase jumlah sampel uji yang terklasifikasi dengan benar pada suatu kelas. User accuracy (Commission Error) adalah persentase jumlah sampel uji yang terklasifikasi dengan benar dari jumlah sampel uji klasifikasi kelas tersebut. Sebuah statistik K (Kappa) digunakan untuk menilai akurasi klasifikasi dari matriks kesalahan dan uji statistik (Z statistik) untuk menguji jika dua error matriks independen berbeda secara signifikan atau tidak.

\section{HASIL DAN PEMBAHASAN}

\subsection{Skema Klasifikasi}

Nilai ketidakmiripan objek koefisien Bray-Curtis pada penelitian ini adalah sebesar $40 \%$, yang menunjukkan klasifikasi habitat bentik yang diidentifikasi memiliki kemiripan sebesar $60 \%$. Belum ada ketentuan dalam pemilihan skala/nilai ketidakmiripan (dissimilarities) untuk mendefinisikan skema klasifikasi. Hal ini disebabkan karena perbedaan kondisi dan variasi lokasi pengamatan dan resolusi citra yang digunakan (Green et al., 2000). Karakteristik dari koefisien dissimilarity adalah membuat formulasi dalam bentuk dendogram. Data input (data lapangan, in situ) dibentuk menjadi plot-plot tergantung pada tujuan penelitian (Ricotta dan Podani, 2017).

Persentase data lapangan menghasilkan 9 kelas untuk Pulau Sebaru Besar dan 10 kelas untuk Pulau Lancang dengan Citra Worldview 2, sedangkan pada Citra Sentinel 2B terdapat 8 kelas untuk Pulau Sebaru Besar dan 9 kelas untuk Pulau Lancang dengan analisis AHC. Hasil yang didapat berupa pure class dan mix class. Mix class merupakan kelas yang didalamnya terdapat dua sampai tiga kelas habitat bentik yang dominan pada suatu titik pengamatan.

Penamaan kelas habitat bentik untuk mix class bergantung pada persentase yang lebih mendominasi. Salah satu contoh mix class yaitu kelas Karang Hidup bercampur Pasir (KHP) yang artinya persentase yang dominan terdapat pada kelas Karang Hidup dan kelas co-dominant terdapat pada kelas pasir. Skema klasifikasi pada Citra Worldview 2 dan Sentinel 2B memiliki perbedaan dalam penamaan kelompok kelas habitat. Hal ini disebabkan oleh pengamatan persentase tutupan habitat bentik untuk klasifikasi pada Citra Worldview 2 menggunakan transect quadrat $1 \mathrm{~m} \times 1 \mathrm{~m}$ sedangkan Citra Sentinel 2B menggunakan ukuran transect quadrat $10 \mathrm{~m} \times 10 \mathrm{~m}$. Hal ini menghasilkan persentase tutupan habitat bentik yang berbeda meskipun di lokasi yang sama. Perbedaan skema klasifikasi Pulau Sebaru Besar dapat dilihat pada Figure 2 dan 3, sedangkan pada Pulau Lancang dapat dilihat pada Figure 4 dan 5.

\subsection{Hasil Klasifikasi}

Skema klasifikasi pada perairan dangkal Pulau Sebaru Besar dikelompokkan menjadi 9 kelas habitat pada Citra Worldview 2 dan 8 kelas pada Citra Sentinel 2B. Penggambaran setiap kelas tersebut menghasilkan luas yang berbeda pada setiap algoritma yang digunakan (Figure 2).

Kemampuan setiap algoritma untuk mengklasifikasikan habitat bentik pada suatu perairan berbeda-beda. Hasil kelas-kelas habitat bentik perairan dangkal Pulau Sebaru Besar dengan Citra Worldview 2 menggunakan algoritma SVM didominasi oleh kelas habitat PS dengan luas 35,2 ha. Algoritma KNN didominasi oleh kelas AP dan PS dengan luas masing-masing 23,8 ha dan 19,7 ha sedangkan pada algoritma DT didominasi oleh kelas AP dan PS dengan luas masingmasing 23 ha dan 17,7 ha. Pada Citra Sentinel 2B dengan algoritma SVM didominasi oleh kelas KHR (53,69 ha). Algoritma KNN didominasi oleh kelas AP (24,58 ha) sedangkan algoritma DT didominasi kelas Karang Hidup campur Pasir (KHP) dengan luas 23,3 ha (Figure 3).

Skema klasifikasi perairan dangkal Pulau Lancang dikelompokkan menjadi 10 kelas habitat pada Citra Worldview 2 dan 9 kelas pada Citra Sentinel 2B. Hasil kelaskelas habitat bentik perairan dangkal Pulau 


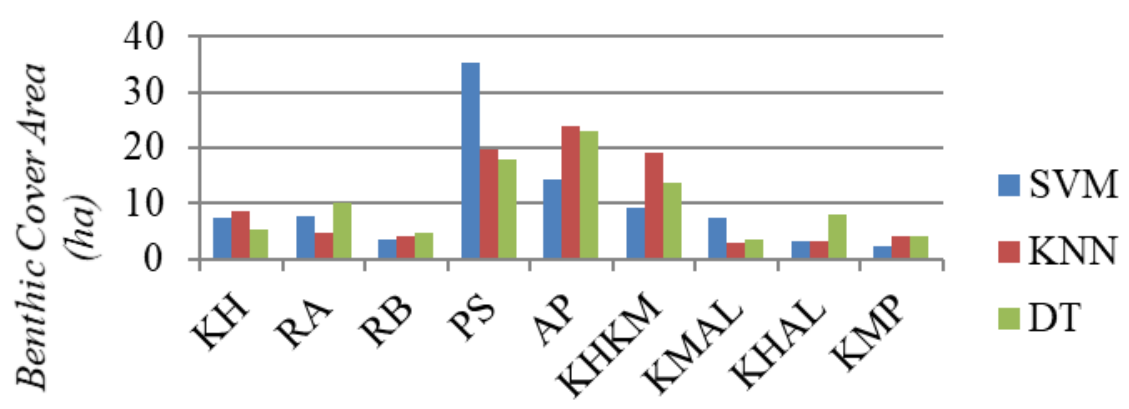

Benthic Habitat Class

Figure 2. Comparison of benthic habitat area in Worldview 2 Imagery using SVM, KNN and DT algorithm in Sebaru Besar Island. Information: Live Coral (KH), Rubble Algaee (RA), Rubble (RB), Sand (PS), Algaee Sand (AP), Live Coral Dead Coral (KHKM), Dead Coral Algaee (KMAL), Live Coral Algaee (KHAL), Dead Coral Sand (KMP).

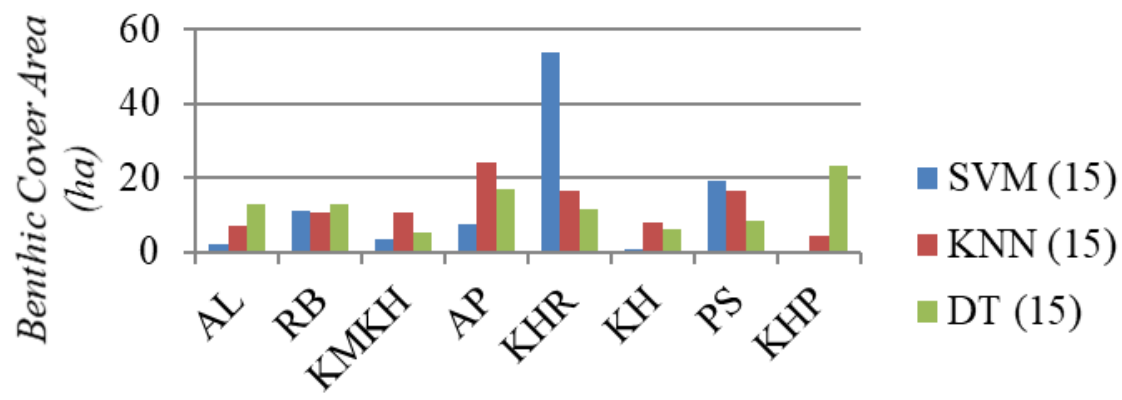

Benthic Habitat Class

Figure 3. Comparison of benthic habitat area in Sentinel 2B Imagery using SVM, KNN and DT algorithm in Sebaru Besar Island. Information: Algae (AL), Rubble (RB), Dead Coral Live Coral (KMKH), Live Coral Rubble (KHR), Live Coral (KH), Sand (PS), Live Coral Sand (KHP).

Lancang dengan Citra Worldview 2 algoritma SVM lebih didominasi oleh kelas habitat Algae (AL) dengan luas 42,9 ha. Algoritma KNN didominasi oleh kelas RB dan RKM dengan luas masing-masing 37,2 ha dan 29 ha sedangkan pada algoritma DT didominasi oleh kelas PS dan RKM dengan luas masing-masing 31,3 ha dan 31,2 ha (Figure 4). Pada Citra Sentinel 2B dengan algoritma SVM didominasi oleh kelas KMPR (49,8 ha) dan RB (49,28 ha). Algoritma KNN didominasi oleh kelas RB (46,02 ha) dan KMPR (40,68 ha) sedangkan algoritma DT didominasi kelas RB dengan luas 37,34 ha dan PL (29,91 ha) (Figure 5).
Perbedaan kelas klasifikasi habitat bentik perairan dangkal Pulau Sebaru Besar dan Pulau Lancang disebabkan oleh beberapa faktor yaitu, resolusi citra, algoritma klasifikasi dan kesalahan data untuk klasifikasi. Kesalahan data yang dimaksud adalah kesalahan dalam hal yang berkaitan dengan teknis di lapangan, yaitu kesalahan pengambilan jumlah sampel, teknis pengambilan sampel (size transect quadrat) dan kesalahan dalam mempresentasikan tutupan habitan bentik. Kesalahan dalam proses klasifikasi akan memberikan pengaruh pada luasan, hal ini dapat mengakibatkan rendahnya akurasi (Prabowo et al., 2018). 


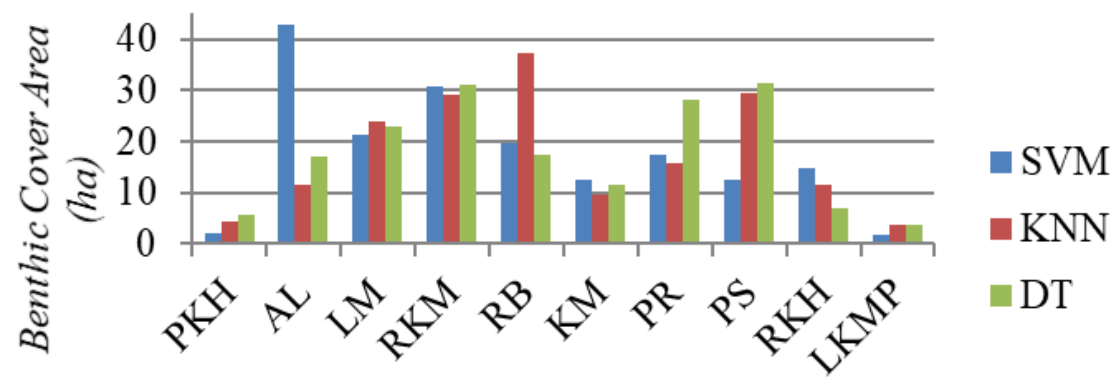

Benthic Habitat Class

Figure 4. Comparison of benthic habitat area in Worldview 2 Imagery using SVM, KNN and DT algorithm in Lancang Island. Information: Sand Live Coral (PKH), Algae (AL), Seagrass (LM), Rubble Dead Coral (RKM), Rubble (RB), Sand (PS), Dead Coral (KM), Sand Rubble (PR), Rubble Live Coral (RKH), Seagrass Dead Coral Sand (LKMP).

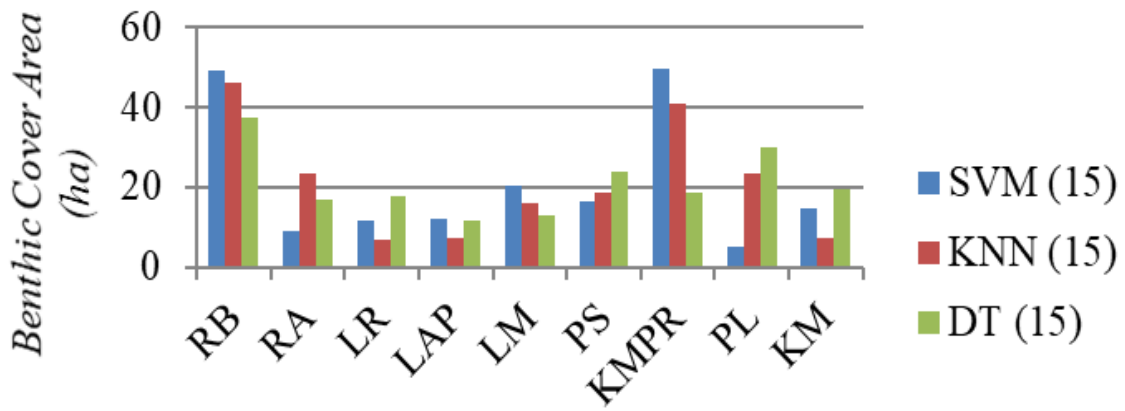

\section{Benthic Habitat Class}

Figure 5. Comparison of benthic habitat area in Sentinel 2B Imagery using SVM, KNN and DT algorithm in Lancang Island. Information. Information: Rubble (RB), Rubble Algae (RA), Seagrass Rubble (LR), Seagrass Algae Sand (LAP), Seagrass (LM), Sand (PS), Dead Coral Sand Rubble (KMPR), Sand Seagrass (PL), Dead Coral (KM).

Bagian utama pada klasifikasi dengan OBIA adalah penentuan skala segmentasi. Penentuan skala segmentasi dipengaruhi oleh resolusi citra yang digunakan, tingkat heterogenitas atau kompleksitas habitat bentik perairan dangkal dan luas lokasi penelitian. Faktorfaktor tersebut dapat menyebabkan perbedaan jumlah, bentuk poligon dan luas masingmasing kelas habitat, sehingga memengaruhi pemetaan sebaran habitat bentik.

\subsection{Hasil Pengukuran Chl-a dan TSS}

Perairan dangkal Pulau Lancang yang memiliki tingkat konsentasi Chl-a lebih ting- gi dibandingkan dengan perairan dangkal Pulau Sebaru Besar. Rata-rata konsentrasi Chl-a pada perairan dangkal Pulau Sebaru Besar dana Pulau Lancang masing-masing sebesar 2,4 $\mu \mathrm{g} / \mathrm{l}$ dan 9,8 $\mu \mathrm{g} / \mathrm{l}$. Besarnya konsentrasi Chl-a dan larutan tersuspensi memiliki pengaruh langsung pada kejelasan, kekeruhan, warna dan sifat optik di perairan (Kirk, 1994; Ouillon et al., 2008). Pada perairan jernih lebih optimal mengabsorpsi energi cahaya, sehingga energi akan menembus (penetrasi) hingga dalam perairan.

Akurasi pemetaan habitat bentik perairan dangkal dengan konsentasi Chl-a yang 
tinggi pada umumnya lebih rendah dibandingkan dengan perairan yang konsentrasi Chl-a lebih rendah (Figure 6). Hal ini menunjukkan bahwa perubahan sifat optik air laut dan peningkatan kekeruhan perairan dapat memengaruhi hasil dari perekaman citra satelit, namun dalam penelitian ini belum dapat dikatakan bahwa tingginya konsentrasi Chl-a dan TSS menjadi penyebab rendahnya akurasi dalam pemetaan habitat bentik. Hal ini disebabkan konsentrasi Chl-a 2,4-9,8 $\mu \mathrm{g} / \mathrm{l}$ pada penelitian ini termasuk perairan dengan tingkat kecerahan $100 \%$ dan juga terdapat perbedaan waktu antara pengambilan sampel dan akuisisi citra satelit yang digunakan. Pada perairan jernih lebih optimal mengabsorpi energi cahaya, sehingga pantulan akan ditangkap hingga dalam perairan.

Absorption dan scattering merupakan faktor penting dalam mendeskripsian nilai $K d$ (atenuasi) di perairan. Nilai $K d$ sebagian besar ditentukan oleh material yang ada diperairan yang berkorelasi dengan konsentrasi klorofil (Guifen et al., 2008) dan juga tergantung pada kedalaman perairan (Groetsch et al., 2011). Chl-a pada perairan akan mengabsorpi cahaya yang masuk ke dalam kolom air sehingga menyebabkan pelemahan cahaya (atenuasi). Nilai $\mathrm{Kd}$ perlahan akan berubah (semakin menurun) dengan bertambahnya kedalaman (Groetsch et al., 2011). Pengukuran kecerahan perairan menggunakan secchi disk berdasarkan sensitivitas mata manusia. Kesalahan dalam pengamatan kemungkinan akan menjadi lebih besar karena kondisi permukaan air yang disebabkan oleh cuaca dan gelombang yang memengaruhi deteksi dari secchi disk. Salah satu faktor yang dapat mengurangi korelasi dari atenuasi dan secchi disk adalah jumlah dari cyanobacteria (Algae hijau/Chl- a) (Jamu et al., 1999). Hochberg \& Atkinson (2003) menyatakan rendahnya akurasi dalam pemetaan habitat dapat dipengaruhi oleh berbagai hal, yaitu jenis sensor, resolusi citra dan kondisi lingkungan perairan seperti kedalaman, kualitas perairan, dan kondisi permukaan laut.

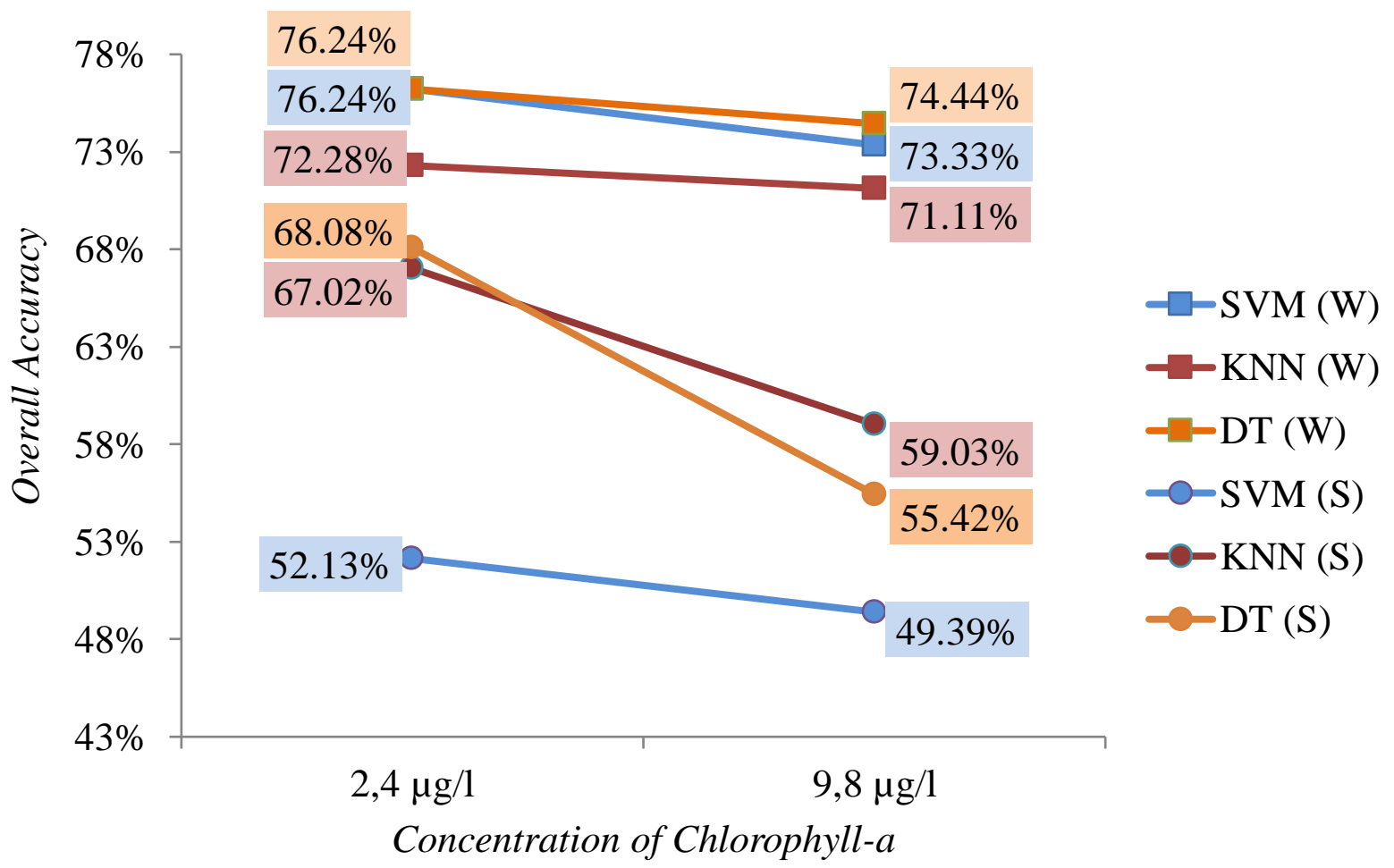

Figure 6. Comparison of accuracy of SVM, KNN and DT algorithms based on chlorophyll-a concentration levels. Information: (W) Worldview 2 Image, (S) Sentinel 2B Image. 


\subsection{Akurasi Klasifikasi OBIA}

Akurasi klasifikasi dihitung dengan menggunakan matriks kesalahan (confision matrix) dari 101 titik pengamatan Pulau Sebaru Besar dan 90 titik pengamatan Pulau Lancang. Hasil OA tertinggi didapat pada klasifikasi habitat bentik Pulau Sebaru Besar dengan Citra Worldview 2 dari algoritma SVM dan DT sebesar 76,24\% (Figure 7), sedangkan di Pulau Lancang yang dihasilkan dari algoritma DT diperoleh OA sebesar $74,44 \%$ (Figure 8). Hasil OA tertinggi klasifikasi habitat bentik dengan Citra Sentinel 2B dihasilkan oleh algoritma DT dengan nilai 68,08\% di Pulau Sebaru Besar (Figure 7) sedangkan pada Pulau Lancang pada algoritma KNN dengan nilai 59,04\% (Figure 8).

Qian et al. (2015) menyatakan bahwa penggunaan algortima SVM akan menghasilkan akurasi yang lebih baik pada jumlah titik pengamatan lebih besar atau sama dengan 125 per kelas, algoritma DT akan menghasilkan akurasi yang relatif stabil ketika kedalaman maksimum lebih besar atau sama dengan $5 \mathrm{~m}$, sedangkan algoritma KNN akan menghasilkan akurasi yang baik dengan menggunakan param $\mathrm{k}$ antara satu atau tiga. Pemetaan habitat bentik pada Pulau Harapan dengan 9 kelas habitat dengan algoritma SVM menghasilkan OA sebesar $75 \%$ (Prabowo et al., 2018). Pemetaan land use dengan menggunakan algoritma SVM dan KNN menghasilkan OA dengan 4 kelas masing-masing sebesar 86-90\% (Tzotsos, 2006) dan 97\% (Gupta et al., 2014). Secara umum hasil akurasi dipengaruhi oleh proses segmentasi, resolusi citra satelit dan karakteristik daerah penelitian.

Faktor yang menyebabkan rendahnya akurasi dalam penelitian ini dipengaruhi oleh jumlah kelas habitat bentik, resolusi citra dan algoritma klasifikasi yang digunakan serta kondisi lingkungan perairan (kualitas per- airan). Hasil akurasi pada penelitian ini menunjukkan bahwa penggunaan algoritma SVM, KNN dan DT dengan Citra Worldview 2 pada Pulau Sebaru Besar dan Pulau Lancang serta algoritma KNN dan DT dengan Citra Sentinel 2B pada Pulau Sebaru Besar mampu memetakan habitat bentik dengan baik. Hal ini dinyatakan oleh Green et al. (2000) bahwa akurasi pemetaan habitat bentik yang dapat digunakan adalah dengan $\mathrm{OA}>60 \%$.

Figure 7 menunjukkan perbedaan sebaran habitat bentik pada Citra Worldview 2 dan Citra Sentinel 2B. Sebaran habitat bentik pada Citra Worldview 2 lebih didominasi kelas Pasir (PS) sedangkan pada Citra Sentinel 2B didominasi oleh kelas Karang Hidup bercampur Pasir (KHP). Variasi sebaran habitat bentik pada kedua citra terdapat pada daerah sekitar tubir dengan kedalaman 1,5 sampai dengan $6 \mathrm{~m}$. Perbedaan sebaran habitat bentik pada Pulau Lancang dengan Citra Worldview 2 dan Citra Sentinel 2B terlihat signifikan (Figure 8). Sebaran kelas habitat bentik pada Citra Worldview 2 didominasi oleh kelas PS dan RKM. Sebaran kelas PS lebih banyak pada bagian selatan pulau sedangkan kelas RKM terdapat hampir diseluruh tubir Pulau Lancang, sedangkan pada Citra Sentinel 2B dengan algoritma $\mathrm{KNN}$ didominasi kelas Rubble (RB). Variasi sebaran kelas habitat bentik dengan Citra Sentinel 2B terdapat pada daerah tubir. Table 2 memperlihatkan varian dari statistik Kappa dan Z statistik. Nilai Z statistik untuk dua matriks kesalahan algoritma SVM pada Pulau Sebaru Besar dan algoritma DT dan SVM pada Pulau Lancang memiliki nilai masing-masing yaitu 2,47 dan 2,51, sehingga kedua algoritma klasifikasi dapat dikatakan berbeda signifikan. Nilai Z statistik dikatakan berbeda signifikan jika hasil $\mathrm{Z}$ statistik lebih besar dari 1,96 (Congalton \& Green, 2008). 
Table 1. Overall accuracy results for benthic habitat classification.

\begin{tabular}{cccc}
\hline $\begin{array}{c}\text { Satellite } \\
\text { Imagery }\end{array}$ & $\begin{array}{c}\text { Classification } \\
\text { Algorithm }\end{array}$ & Sebaru Besar Island & Lancang Island \\
\hline Worldview 2 & SVM & $76.24 \%$ & $73.33 \%$ \\
& KNN & $72.28 \%$ & $71.11 \%$ \\
Sentinel 2B & DT & $76.24 \%$ & $74.44 \%$ \\
& SVM & $52.13 \%$ & $49.40 \%$ \\
& KNN & $67.02 \%$ & $59.04 \%$ \\
& DT & $68.08 \%$ & $55.42 \%$ \\
\hline
\end{tabular}
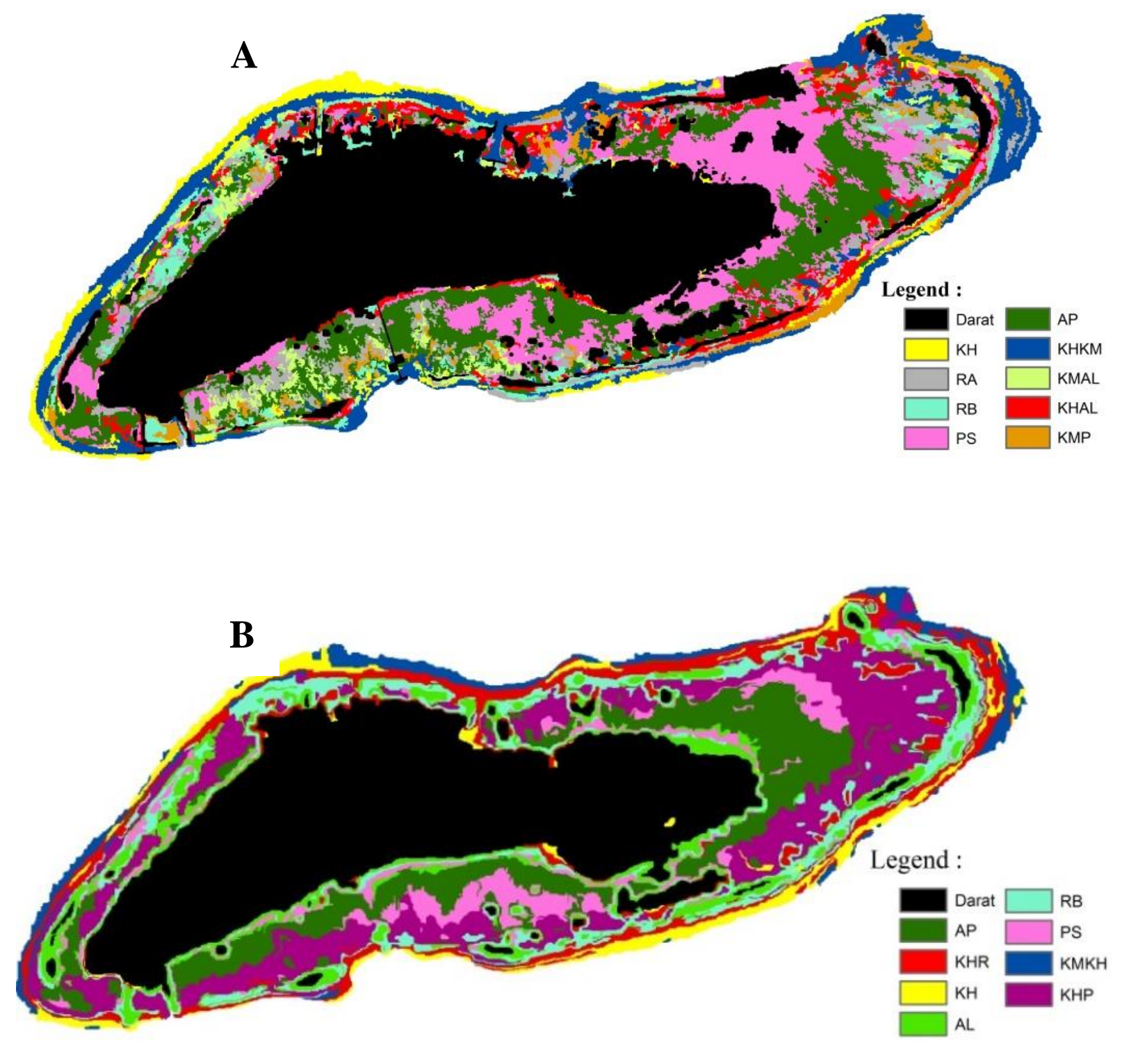

Figure 7. Map of the benthic habitat classification of Sebaru Besar Island (A) Worldview 2 image with SVM algorithm (B) Sentinel 2B image with DT algorithm. 

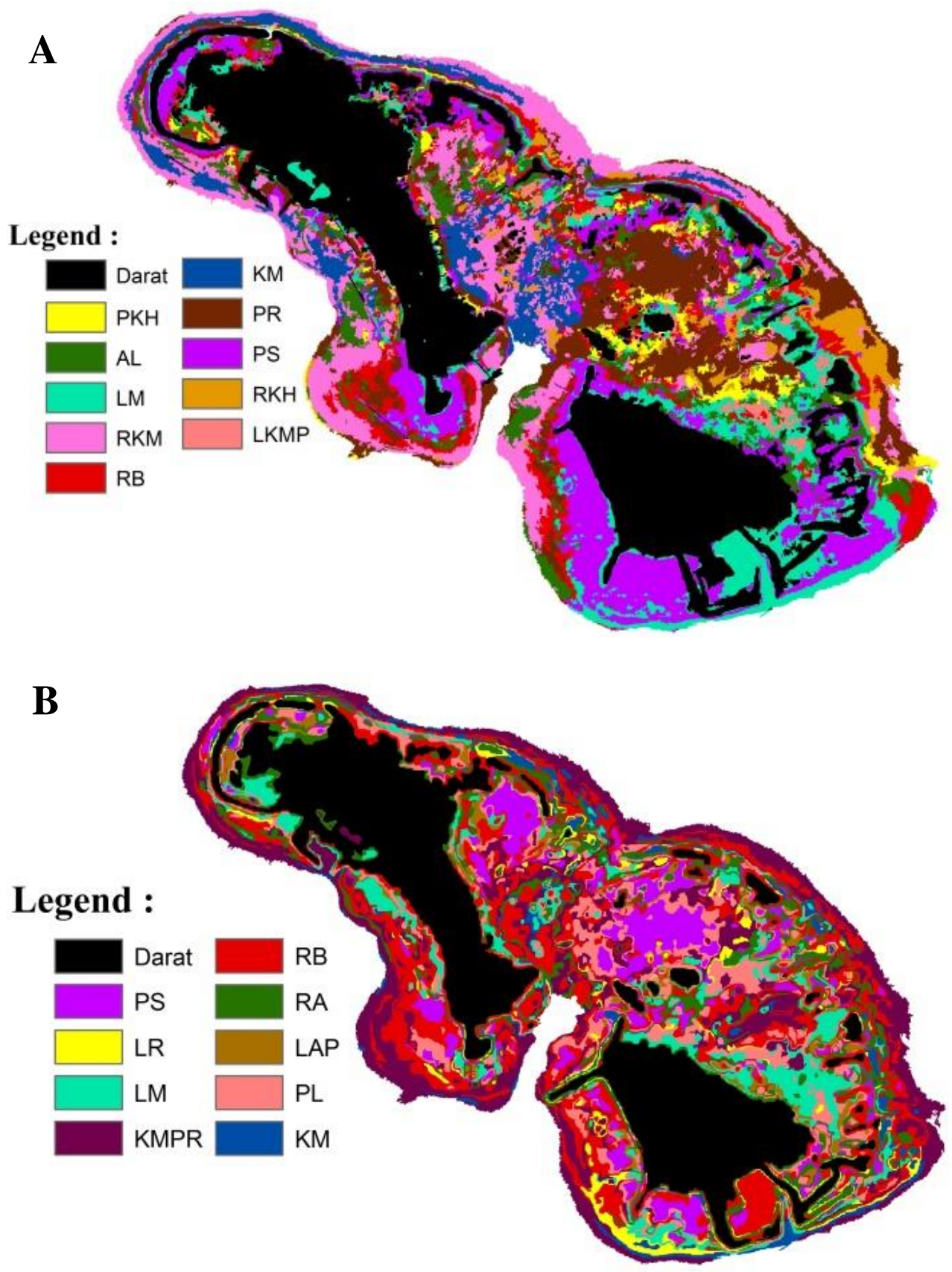

Figure 8. Map of the benthic habitat classification of Lancang Island (A) Worldview 2 image with DT algorithm (B) Citra Sentinel $2 B$ with KNN algorithm.

Table 2. Kappa and $Z$ statistical analysis results.

\begin{tabular}{lcccc}
\hline \multicolumn{1}{c}{ Shallow Waters } & $\begin{array}{c}\text { Classification } \\
\text { Algorithm }\end{array}$ & Satellite Imagery & Kappa & Z Statistical \\
\hline Sebaru Besar & SVM & Worldview 2 & 0.7232 & 2.47 \\
Island & & Sentinel 2B & 0.4401 & \\
Lancang Island & DT & Worldview 2 & 0.7134 & 2.51 \\
& SVM & Sentinel 2B & 0.4194 & \\
\hline
\end{tabular}




\section{KESIMPULAN}

Habitat bentik perairan dangkal Pulau Sebaru Besar dan Pulau Lancang dapat dipetakan dengan baik menggunakan Citra Worldview 2 dan Sentinel 2B berdasarkan klasifikasi berbasis objek (OBIA). Akurasi keseluruhan tertinggi dihasilkan dengan menggunakan Citra Worldview 2 dengan nilai sebesar 76,24\% dengan 9 kelas pada algortima SVM dan DT dan berdasarkan $Z$ test berbeda signifikan sebesar 2,51. OA tertinggi pada Citra Sentinel 2B dihasilkan oleh algoritma DT sebesar $68,08 \%$ dengan 8 kelas. Konsentrasi Chl-a lebih tinggi pada perairan dangkal Pulau Lancang, namun tingginya konsentrasi Chl-a dan TSS belum dapat dikatakan memengaruhi rendahnya akurasi dalam pemetaan habitat bentik perairan dangkal. Faktor yang memengaruhi perbedaan akurasi pada penelitian ini jumlah klasifikasi, akuisisi citra, resolusi citra dan algoritma yang digunakan.

\section{UCAPAN TERIMA KASIH}

Penulis mengucapkan terima kasih kepada LAPAN (Lembaga Antariksa dan Penerbangan Nasional), Taman Nasional Kepulauan Seribu atas bantuan alat dan fasilitas selama proses pengambilan data lapangan, serta teman-teman yang telah ikut membantu untuk pengambilan data lapangan (in situ). Penulis juga mengucapkan terima kasih kepada reviewer yang telah memberikan masukan untuk meningkatkan kualitas paper ini.

\section{DAFTAR PUSTAKA}

American Public Health Association (APHA). 2012. Standard methods for the examination of water and waste water. Washington DC. $1496 \mathrm{p}$.

Andréfouët, S., F.E.M. Kargera, E.J. Hochberg, C. Hua, \& K.L. Cardera. 2001. Change detection in shallow coral reef environments using Landsat
7 ETM+ data. Remote Sens. Environ., 79: $150-162$.

https://doi.org/10.1016/S00344257(01)00256-5

Atkinson, P.M. \& D.K. Naser. 2010. A Geostatistically Weighted K-NN Classifier for Remotely Sensed Imagery. Geogr. Anal., 42(2): 204-225. https://doi.org/10.1111/j.15384632.2010.00790.x

Blaschke, T., G.J. Hay, M. Kelly, S. Lang, P. Hofmann, E. Addink, R.Q. Feitosa, F. Meer, H. Werff, F. Coillie, \& D. Tiede. 2014. Geographic ObjectBased Image Analysis - Towards a new paradigm. ISPRS J. of Photogrammetry and Remote Sensing, 87: 180-191. https://doi.org/10.1016/j.isprsjprs.201 3.09.014

Chen, J., T. Cui, J. Tang, \& Q. Songe. 2014. Remote sensing of diffuse attenuation coefficient using MODIS imagery of turbid coastal waters: A case study in Bohai Sea. Remote Sens. Environ., 140: 78-93. https://doi.org/10.1016/j.rse.2013.08. 031

Congalton, R.G. \& Green K. 2008. Assessing the accuracy of remotely sensed data: principles and practices. CRC Press: Taylor \& Francis Group. France. 27 p.

Firmansyah, I., E. Riani, \& R. Kurnia. 2012. Model pengendalian pencemaran laut untuk meningkatkan daya dukung lingkungan Teluk Jakarta. J. of Natural Resources and Environmental Management, 2(1): 22-28. http://doi.org/10.29244/jpsl.2.1.22

Green, E.P., P.J. Mumby, A.J. Edwards, \& C.D. Clark. 2000. Remote sensing handbook for tropical coastal management. United Nations Educational, Scientific and Cultural 
Organization (UNESCO). Paris. 325 p.

Groetsch, P. 2011. Optimization and verification of a new analytical radiative transfer model. Deutschen Luft- und Raumfahrtzentrum. Munchen (Germany). 89 p.

Guifen, W., W. Cao, D. Yang, \& D. Xu. 2008. Variation in downwelling diffuse attenuation coefficient in the northern South China Sea. Chin. J. Oceanol. Limn., 26: 323-333. https://doi.org/10.1007/s00343-0080323-x

Gupta, N., M. Tech, \& P. Garhwal. 2014. Object based information extraction from high resolution satellite imagery using eCognition. International J. of Computer Science Issues, 11: 139144. https://ijcsi.org/papers/IJCSI-113-2-139-144.pdf

Hochberg, E.J. \& M.J. Atkinson. 2003. Capabilities of remote sensors to classify coral, Algaee, and sand as pure and mixed spectra. Remote Sens. Environ., 85: 174-189.

https://doi.org/10.1016/S00344257(02)00202-X

Jamu, D.M., Z. Lu, \& R.H. Piedrahita. 1999. Relationship between Secchi disk visibility and chlorophyll a in aquaculture ponds. Aquac., 170: 205214.

https://doi.org/10.1016/S00448486(98)00405-0

Keller, B.D., B.D. Keller, D.F. Gleason, E. McLeod, C.M. Woodley, S. Airame, B.D. Causey, A.M. Friedlander, R.G. Dunsmore, J.E. Johnson, S.L. Miller, \& R.S. Steneck. 2009. Climate change, coral reef ecosystems, and management options for marine protected areas. Environmental Management, 44: 1069-1088. https://doi.org/10.1007/s00267-0099346-0
Kirk, J.T.O. 1994. Light and photosynthesis in aquatic ecosystems. Cambridge university press. Australia. $471 \mathrm{p}$.

Liao, H. \& W. Sun. 2010. Forecasting and evaluating water quality of chao lake based on an improved decision tree method. Procedia Environ. Sci., 2: 970-979. https://doi.org/10.1016/j.proenv.2010. 10.109

Mastu, L.O.K, B. Nababan, \& P.J. Panjaitan. 2018. Pemetaan habitat bentik berbasis objek menggunakan citra sentinel-2 di Perairan Pulau WangiWangi Kabupaten Wakatobi. J. Ilmu dan Teknologi Kelautan Tropis, 10: 381-396. https://doi.org/10.29244/jitkt.v10i2.21 039

Ouillon, S., P. Douillet, A. Petrenko, J. Neveux, C. Dupouy, J.M. Froidefond, S. Andréfouët, \& A.M. Caravaca. 2008. Optical algorithms at satellite wavelengths for total suspended matter in tropical coastal waters Sensors. Sensors (Basel), 8(7): 41654185. https://doi.org/10.3390/s8074165

Pena, J.M., J.T. Sánchez, A.I. Castro, M. Kelly, \& F.L. Granados. 2013. Weed mapping in early-season maize fields using object-based analysis of unmanned aerial vehicle (UAV) images. Plos One, 8: 1-11. https://doi.org/10.1371/journal.pone.0 077151

Peng, S., R. Zhou, X. Qin, H. Shi, \& D. Ding. 2013. Application of macrobenthos functional groups to estimate the ecosystem health in a semienclosed bay. Mar. Pollut., 74: 302-310.

https://doi.org/10.1016/j.marpolbul.20 13.06.037

Prabowo, N.W., V.P. Siregar, \& S.B. Agus. 2018. Classification of benthic habitat based on object with support vector machines and decision tree algorithm 
using spot-7 multispectral imagery in Harapan and Kelapa Island. J. Ilmu dan Teknologi Kelautan Tropis, 10(1): 123-134.

https://doi.org/10.29244/jitkt.v10i1.21 670

Qian, Y., W. Zhou, J. Yan, W. Li, \& L. Han. 2015. Comparing machine learning classifiers for object-based land cover classification using very high resolution imagery. Remote Sens., 7: 153-168. https://doi.org/10.3390/rs70100153

Ricotta, C. \& J. Podani. 2017. On some properties of the Bray-Curtis dissimilarity and their ecological meaning. Ecological Complexity, 31: 201-205. https://doi.org/10.1016/j.ecocom.2017 .07 .003

Roelfsema, C., S. Phinn, S. Jupiter, J. Comley, M. Beger, \& E. Paterson. 2010. The application of object based analysis of high spatial resolution imagery for mapping large coral reef systems in The West Pacific at Geomorphic and Benthic Community Spatial Scales. Editor Proceedings of 2010 IEEE International Geoscience and Remote Sensing Symposium, 4346-4349 pp.

https://doi.org/10.1109/IGARSS.2010 .5654126
Sugiyono. 2008. Metode Penelitian kuantitatif kualitatif dan R\&D. Alfabeta. Bandung. 213 p.

Tzotsos, A. 2006. A support vector machine approach for object based image analysis. Proceedings of OBIA. 1-7 pp.

https://www.researchgate.net/publicat ion/235964591

Verhulp, J. \& A.V. Niekerk. 2017. Transferability of decision trees for land cover classification in a heterogeneous area. South African J. of Geomatics, 6: 30-46. https://doi.org/10.4314/sajg.v6i1.3

Wahidin, N., V.P. Siregar, B. Nababan, I. Jaya, \& S. Wouthuyzend. 2015. Object-based image analysis for coral reef benthic habitat mapping with several classification algorithms. Procedia Environ. Sci., 24: 222-227. https://doi.org/10.1016/j.proenv.2015. 03.029

Wei, W., X. Chen, \& A. Ma. 2005. Objectoriented information extraction and application in high-resolution remote sensing image. IEEE International Geoscience and Remote Sensing Symposium, 8: 3803-3807.

Received : 23 May 2019

Reviewed : 17 October 2019

Accepted : 29 July 2020 
